\title{
ACTIVITY OF GLYCOSIDASES FROM FRESHWATER HETEROTROPHIC MICROORGANISMS ON THE DEGRADATION OF EXTRACELLULAR POLYSACCHARIDE PRODUCED BY ANABAENA SPIROIDES (CYANOBACTERIA)
}

\author{
Vanessa Colombo $^{1 *}$; Armando A.H. Vieira ${ }^{1}$; Gilberto Moraes ${ }^{2}$ \\ ${ }^{1}$ Departamento de Botânica, Universidade Federal de São Carlos, São Carlos, SP, Brasil; ${ }^{2}$ Departamento de Genética e Evolução, \\ Universidade Federal de São Carlos, São Carlos, SP, Brasil.
}

Submitted: October 08, 2002; Returned to authors: July 25, 2003; Approved: April 13, 2004.

\begin{abstract}
The activity of specific glycosidases during the degradation of the extracellular polysaccharide (EPS) produced by Anabaena spiroides was determined using MUF-substrates (MUF-monosaccharides). Polysaccharide degradation was found to occur in a two-phase process. The first consisted of high enzymatic activity that consumed $41 \%$ of the EPS at a relatively high rate, while the second consumed the remaining polysaccharide (59\%) at a slower rate. A transition phase from the higher to the slower degradation rates was marked by a replacement of bacterial populations from coccoid to bacillus cells. During the degradation process, the bacterial biomass increased with the decrease of EPS, as revealed by bacterial cell counts. The enzymatic activity detected through the substrates MUF- $\alpha-D-$ and MUF- $\beta-D-$ glucoside was higher than that detected by other substrates tested. The remaining glycosides were MUF- $\alpha$-L-rhamnopyranoside, MUF- $\beta$-Dgalactoside, MUF- $\alpha$-D-mannopyranoside, MUF- $\beta$-D-fucoside, MUF- $\beta$-D-mannopyranoside, MUF- $\alpha$-Larabinopyranoside, and MUF- $\beta$-L-fucoside. The fluorescence emitted by each MUF-substrate was proportional to the concentration of the corresponding monosaccharide in A. spiroides EPS. This demonstrates the susceptibility of EPS produced by A. spiroides to enzymatic attack by bacterial populations.
\end{abstract}

Key words: Anabaena spiroides, glycosidases, extracellular polysaccharides, degradation, heterotrophic microorganisms

\section{INTRODUCTION}

The main producers of glycosidases in aquatic environments (water and sediments) are microheterotrophic organisms, mostly bacteria and fungi $(4,24)$. Ectoenzymes (membrane-bound enzymes) and extracellular enzymes (free or surface adsorbedenzymes) play a significant role in the ecology of aquatic environments because, allied with grazing, they are responsible for the degradation process by which detritus enter the food chain (14). This catalytic activity is necessary because approximately $95 \%$ of the dissolved organic matter in aquatic environments is composed of high molecular weight polymeric compounds (4).
The enzymatic activity in aquatic environments was first reported in 1906, when Fermi (9) observed the activity of proteolytic enzymes in the stagnant water of a pool. However, it was only in the 80 's, after the publication of a pioneering study in which fluorescent substrates were used to investigate hydrolases present in natural environments (12) that the investigation of these enzymes received a strong boost. The methylumbelliferyl-substrates (MUF-substrates) are hydrolyzed extracellularly which has been demonstrated by several authors $(3,12,13,19,24)$. Martinez and Azam (18) verified that the activity registered by these substrates originates from periplasmic and other extracellular enzymes and not from cytoplasmic enzymes.

*Corresponding author. Mailing address: Departamento de Botânica, Universidade Federal de São Carlos. 13565-905, São Carlos, SP, Brasil. Tel.: (+5516) 2608311. Fax: (+5516) 2608308. E-mail: pvcol@iris.ufscar.br 
The microbial and algal extracellular polysaccharides (EPS) can be attacked by the ectoglycosidases and/or extracellular glycosidases either endogenously or exogenously, depending on the position of attacked linkages in the polymer chain, leading to rapid or slow breakdown, respectively (26).

Anabaena spiroides (Klebahn) is a filamentous cyanobacterium whose cell wall is covered externally by a wide polysaccharidic capsule that continuously releases material into the medium. It is usually present in eutrophic water bodies such as the Barra Bonita reservoir, located in the state of São Paulo, Brazil, where its population plays an important ecological role, contributing with Microcystis aeruginosa for cyanobacterial dominance in such environment. Together with most of the dominant species of the reservoir (Microcystis spp, Planktothrix sp, Kirchneriella obesa, Staurastrum spp), A. spiroides contributes to a great proportion for the biomass produced via photosynthesis. Part of this biomass comprise released EPS which can account theoretically for $12.10^{9}$ mg year ${ }^{-1}$ of carbohydrates as extracellular polysaccharides in the entire reservoir (area $324.84 \mathrm{~km}^{2}$, mean depth $10.2 \mathrm{~m}$, maximum depth $20.2 \mathrm{~m}$ ) (value calculated from primary productivity measurements obtained by Calijuri and Dos Santos (1)).

A. spiroides may form large blooms during periods of long retention times and low turbulence in the Barra Bonita reservoir (27). These organisms produce considerable amount of EPS that is released into the medium in the form of colloids. Some researchers claim that these polymers accumulate in the environment, suggesting that EPS are not easily utilized by bacteria and, as a result, contribute to the pool of recalcitrant high molecular weight substances in aquatic ecosystems (25). However, if heterotrophic microorganisms degraded them, these compounds would represent an important substrate.

The purpose of this study was to investigate the susceptibility of EPS produced by A. spiroides to enzymatic attack of extracellular enzymes produced by reservoir's natural bacteria populations. We have demonstrated that this bacterial population were able to grow using EPS as carbon source.

\section{MATERIALS AND METHODS}

\section{Organism and culture conditions}

Anabaena spiroides Klebahn (Cyanobacteria) was collected and isolated from the Barra Bonita reservoir, São Paulo State, Brazil (22 32 ' $34.5^{\prime \prime} \mathrm{S}, 48^{\circ} 29^{\prime} 26.4^{\prime \prime} \mathrm{W}$ ), and added to the Freshwater Microalgae Culture Collection of the Botany Department, Federal University of São Carlos (strain 183 CY BB07). Cultures were grown in ASM-1 medium (11) plus TRIS $(500 \mathrm{mg} / \mathrm{l})$ at $23 \pm 1^{\circ} \mathrm{C}(12: 12 \mathrm{~h} \mathrm{~L} / \mathrm{D}$, light intensity between 150 $200 \mu$ mol photon $\mathrm{m}^{-2} \mathrm{~s}^{-1}$ ) under continuous aeration.

\section{Extraction of EPS}

Cells from a batch culture of 181 were removed from the culture medium at the end of the exponential growth phase (30 days old) by tangential filtration in hollow fiber cartridges with $0.65 \mu \mathrm{m}$ pore size membranes (A/G Technology Corporation, Needham, MA, USA). The medium, which contained the released EPS was further concentrated (circa $1,000 \mathrm{ml}$ ) by tangential filtration in hollow fiber cartridges with $30 \mathrm{kDa}$ pore size and washed (diafiltration) three times with three volumes of deionized water to eliminate low molecular weight compounds. The concentrated medium thus obtained was then freeze-dried to obtain the EPS and kept at $-12^{\circ} \mathrm{C}$ until the use.

\section{EPS monosaccharide composition}

The monosaccharide composition was characterized by gas chromatography (GC) analysis of O-trimethyl silyl derivatives of methyl glycosides as described in Reinhold (23), with modifications (21). The protein content was determined according to the method of Lowry et al. (16).

\section{Experiments of EPS degradation by heterotrophic microorganisms}

The water used to dissolve the EPS and carry out the experiment was collected from the Barra Bonita reservoir, using a Niskin bottle in the euphotic $(0,1.25$, and $2.5 \mathrm{~m})$ and aphotic zone $(6.25$ and $11.25 \mathrm{~m})$. These were mixed in equal parts to obtain a vertically integrated sample, and 3,600 $\mathrm{ml}$ was filtered through pre-washed cellulose acetate membrane filters $(0.45$ $\mu \mathrm{m}$ pore size, Millipore Inc., Bedford, Massachusetts, USA), autoclaved and enriched with $300 \mathrm{mg}$ of the EPS produced by A. spiroides $(0.08 \mathrm{mg} / \mathrm{ml})$. A natural microheterotrophic population used as inoculum for the degradation of EPS was obtained using $180 \mathrm{ml}$ of the Barra Bonita integrated water sample, filtered only through a calcinated AP-20 glass fiber filter to retain debris and larger organisms but not bacteria and eventually yeasts. This was then added, under aseptic conditions, to the integrated sample plus EPS to provide the natural microheterotrophic population. This was further divided into two identical replicate samples of $1,800 \mathrm{ml}$. A control was similarly prepared, but without the inoculum. The experimental vessels provided with vent stoppers, were incubated at $25^{\circ} \mathrm{C}$ in the dark, aerated by shaking two or three times a day, and sampled at 24-hour intervals under aseptic conditions during a 30-day period. To estimate bacterial cell numbers, samples were fixed with $4 \%$ formalin immediately after sampling and then stained during 30 minutes with DAPI $(0.125 \mathrm{mg} / \mathrm{ml})$, filtered through $0.2 \mu \mathrm{m}$ black filters Isopore (Millipore) and counted using a fluorescence microscope (22). The amount of EPS left in the experimental vessels was quantified once per day by the phenol-sulfuric reaction (7), which detects total carbohydrates.

Enzyme Assays. The enzymatic activities of the samples were determined by 4-methylumbelliferone (MUF) fluorescence produced when the linkage MUF-monosaccharide is broken by specific hydrolytic activity (5). The MUF-substrates used were: 4-MUF- $\alpha$-L- arabinopyranoside, 4-MUF- $\beta$-D-fucoside, 4-MUF- 
$\beta$-L-fucoside, 4-MUF- $\alpha$-D-glucoside, 4-MUF- $\beta$-D-glucoside, 4MUF- $\beta$-D-galactoside, 4-MUF- $\alpha$-D-mannopyranoside, 4-MUF$\beta$-D-mannopyranoside and 4-MUF- $\alpha$-L-rhamnopyranoside (Sigma Chemical CO, St. Louis, USA). The choice of substrates was based on the monosaccharide composition of A. spiroides EPS identified by gas chromatography. The Chróst and Krambeck (5) protocol was properly adjusted and substrate saturation curves were obtained to establish the best MUFsubstrate concentration. Autoclaved reservoir water was used as a blank. The samples obtained from the experimental vessels were incubated for 30 minutes at $20^{\circ} \mathrm{C}$, after which the reactions were stopped by the addition of $100 \mu \mathrm{L}$ of $5 \mathrm{M} \mathrm{NaOH}$, a procedure also employed to produce the maximum MUF fluorescence. The fluorescence was measured in a Perkin-Elmer 50 model LS B spectrofluorometer (Buckinghamshire, United Kingdom) at $450 \mathrm{~nm}$, under $365 \mathrm{~nm}$ excitation. A MUF-calibration curve was prepared so that the measurements of relative fluorescence could be transformed into $\mathrm{nmol} \mathrm{l}^{-1} \mathrm{~min}^{-1}$.
Gel Permeation Chromatography. To analyze the EPS degradation, the samples were fractionated in a fraction collector Frac-200 LKB (Pharmacia, Uppsala, Sweden), using size exclusion $\left(10^{4}-10^{6} \mathrm{Da}\right)$ chromatography (Sepharose CL-6B, Pharmacia) at room temperature and pH 7.0 in a $1.6 \times 100 \mathrm{~cm}$ column, with a $1.67 \mathrm{ml} / \mathrm{min}$ eluent flow rate (water plus $2 \%$ butanol). The EPS fractions resulting from degradation were detected by the phenol-sulfuric method (7).

\section{RESULTS AND DISCUSSION}

The monomeric composition of the $A$. spiroides EPS analyzed by GC was: $29.3 \%$ of glucose, $24.2 \%$ of mannose, $21.9 \%$ of rhamnose, $7.8 \%$ of xylose, $6.6 \%$ of glucuronic acid, $5.6 \%$ of fucose, $2.0 \%$ of galactose, $1.8 \%$ of galacturonic acid and $0.8 \%$ of arabinose. The EPS also contained $12.2 \%$ of protein.

Gel permeation chromatography of whole EPS (Fig. 1, day 0) and carbohydrate determination of resulting fractions showed

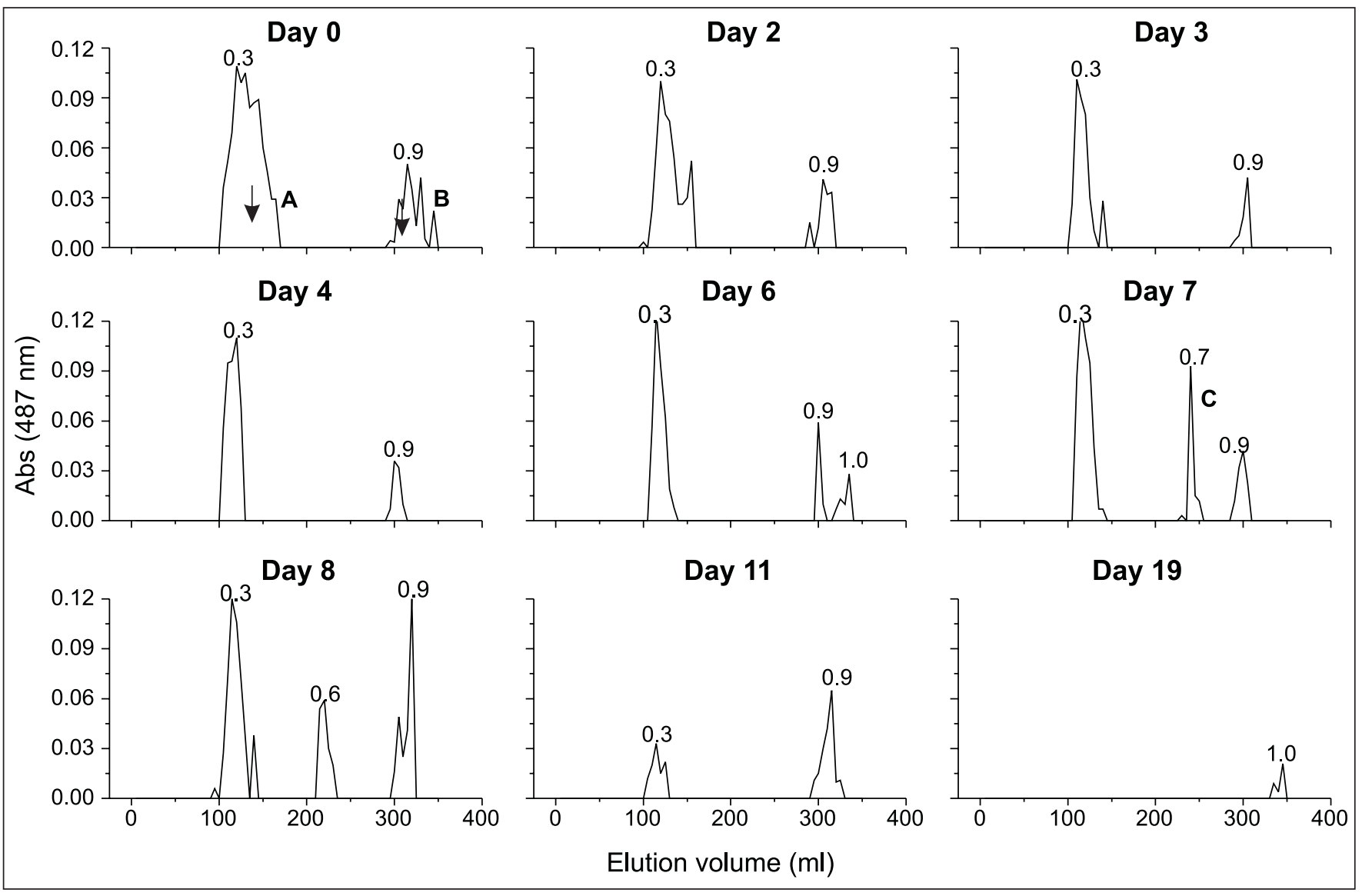

Figure 1. Elution diagrams of gel permeation chromatography in Sepharose CL-6B showing polysaccharide degradation by the microheterotrophic population from the reservoir. A, B and $\mathrm{C}$ are the three fractions detected by phenol-sulfuric acid reaction at $487 \mathrm{~nm}$. The arrows indicate the elution position of dextrans (standards of 2,000 kDa and $10 \mathrm{kDa}$ ). Each peak is identified by its Ve/Vt coefficients. 
that it was constituted by two parts, a high molecular weight fraction (fraction $\mathrm{A}$ ) with $\mathrm{Ve} / \mathrm{Vt}=0.3$, the same as that found for Blue Dextran (reference, 2,000 kDa), and a low molecular weight fraction (fraction $\mathrm{B}$ ) with $\mathrm{Ve} / \mathrm{Vt}=0.9$, close to that found for Dextran T-10 (reference, $10 \mathrm{kDa}$ ). Fraction B may be a fragment of fraction $\mathrm{A}$, since the monosaccharide content was exactly the same in both fractions, despite different relative concentrations.

The degradation of the EPS occurred by the breakdown into smaller fragments relocating the high molecular EPS initial weight (with $\mathrm{Ve} / \mathrm{Vt}=0.3$ ) towards low molecular weight fractions (with $\mathrm{Ve} / \mathrm{Vt}=0.6,0.7,0.9$ and 1.0) until almost a complete degradation (Fig. 1).

Fig. 2a shows that the amount of EPS decreased with the increase of enzymatic activity from the microheterotrophic population of Barra Bonita reservoir. EPS was almost completely degraded in a 29-day period. In fact, the bacterial biomass, measured by cell counts (Fig. 2b), increased during the EPS
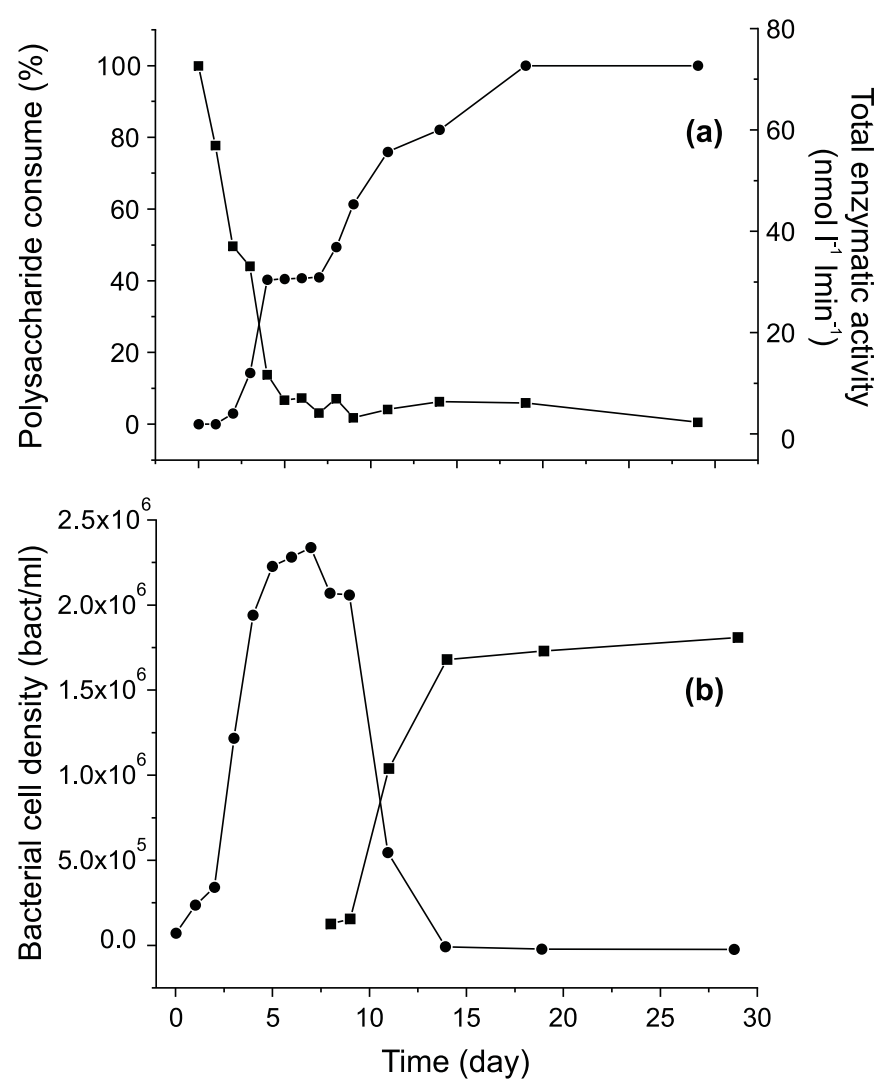

Figure 2. a) Comparison of polysaccharide consumption (- -) and enzymatic activity (- - -) during the experiment. Total enzymatic activity was achieved by the sum of the activities over the nine MUF-substrates for each day and is expressed in nmol $1^{-1} \min ^{-1}$. b) Bacterial counts during the process of EPS degradation. Coccoid cells (- - ) and bacillus cells (-口-). degradation indicating that bacterial populations have used the polymer as a carbon source.

The degradation process was observed to occur in two phases (Fig. 2a, b): the first from zero to 6 days, involving high enzymatic activity (Fig. 3) of coccoid cells that rapidly consumed $41 \%$ of the polysaccharide, and the second, from day 6 to the end of the 29-day period, in which the remaining polysaccharide $(59 \%)$ was consumed more slowly by bacillus cells. The halflife time of the first phase was 4.6 hours (0.19 days), while that of the second was 31.2 hours ( 1.3 days). Therefore, a bacterial population shift from coccoid to bacillus cells was demonstrated to occur as a result of the polysaccharide degradation (Fig. 2b). This shift was marked by both a reduction in degradation rate and quantitative alterations in the relative enzymatic activities, which were higher in the first degradation phase. During the second degradation phase, no enzymatic activity was detected for 4-MUF- $\alpha$-D-glucoside, 4-MUF- $\beta$-D-glucoside and 4-MUF$\alpha$-D-mannopyranoside.

The microbial population dominated by bacillus cells has produced enzymes able to degrade 4-MUF- $\alpha$-L-arabinopyranoside, 4-MUF- $\beta$-D-fucoside, 4-MUF- $\beta$-L-fucoside, 4-MUF- $\beta$-Dgalactoside and 4-MUF- $\alpha$-L-rhamnopyranoside. Adding this to the fact that no bacillus population was present in the first degradation phase, we suggest that, in fact, the bacillus population of the present experiments were unable to degrade the sugar glucose and mannose or else these sugars were totally consumed by the coccoid population.

The faster degradation rate in the present investigation during the first stage is in agreement to what has been reported for bacteria activity grown on polymeric substrates. In fact, Unanue et al. (28) have shown that a marine bacteria population presented high hydrolytic activity at high concentrations of polymeric substrates.

The high enzymatic activity observed during the first phase ( 0 - 5 days) was exclusively due to glucosidases. Considering that we have no evidence concerning the specificity of linkages breakdown in the EPS degradation process, we refer to the term "putative" as for a general enzyme. The sum of all activities of the other putative enzymes in this period is approximately $25 \%$ of the activity registered to the glucosidades (Fig. 3). The highest glucosidase activity measured with 4-MUF- $\alpha-D$ glucoside was about $44 \mathrm{nmol} \mathrm{l}^{-1} \mathrm{~min}^{-1}$. This reflects the large glucose percentage in the EPS from A. spiroides, characteristic of Cyanobacteria exudates, (6). Indeed, the putative enzyme presenting the second highest activity was the one that cleaved 4 MUF- $\alpha$-D-mannopyranoside and 4-MUF- $\beta$-D-mannopyranoside linkages (mannose was the second monosaccharide present in higher concentration in the EPS). Even so this putative 4-MUF$\beta$-D-mannopyranoside presented only $11 \%$ of the $4-M U F-\alpha-D-$ glucoside activity peak.

All the MUF-substrates used in the present work were found to emit fluorescence (Fig. 3). This means that MUF- 

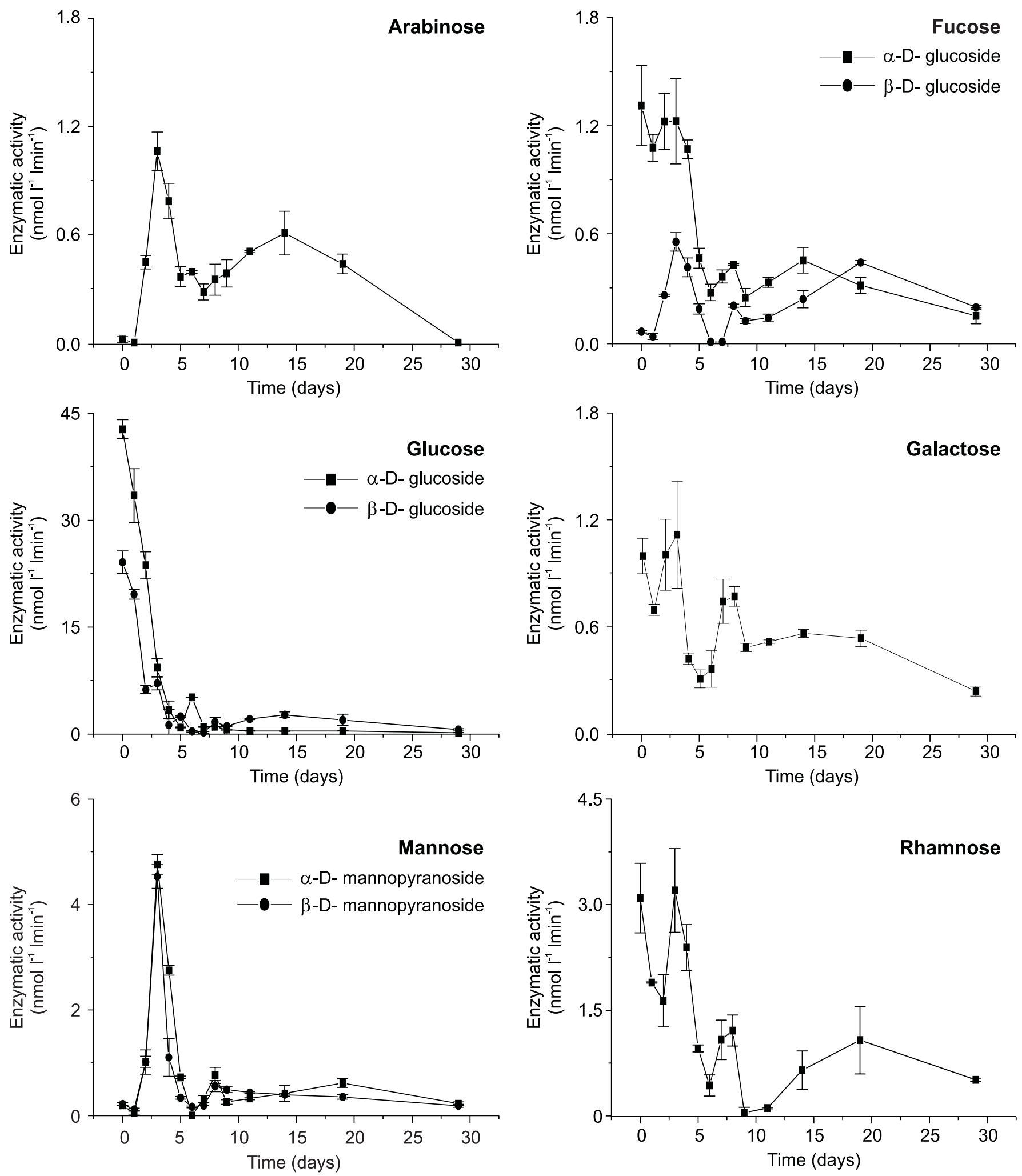

Figure 3. Enzymatic activity $\left(\mathrm{nmol} \mathrm{l}^{-1} \mathrm{~min}^{-1}\right.$ ) associated to the degradation of the A. spiroides EPS obtained by fluorescence of the corresponding MUF-substrate. Note the different scales used. 
monosaccharides linkages were broken by enzymatic activity. This may be deduced because the MUF-glycosides are very stable compounds and the chemical hydrolysis of substrates is improbable except under highly acidic condition (24). A wide range of enzymatic activities was observed in the samples (Fig. 4). The magnitude of the standard deviation (SD) for every MUF-substrate and the mean values were approximately the same. Comparing the relative activities for different substrates, both 4-MUF- $\alpha$-D- and 4-MUF- $\beta$-D-glucosides were cleaved at expressive rates. Discreet hydrolysis was observed when considering the other substrates assayed: 4-MUF- $\alpha-\mathrm{L}-$ rhamnopyranoside, 4-MUF- $\beta$-D-galactoside, 4-MUF- $\alpha$-Dmannopyranoside, 4-MUF- $\beta$-D-fucoside, 4-MUF- $\beta$-Dmannopyranoside, 4-MUF- $\alpha$-L-arabinopyranoside, and 4-MUF$\beta$-L-fucoside. The activity registered on the latter MUFsubstrate was only detectable in trace amounts.

We have observed two basic enzyme activity patterns. Arabinosidase, mannosidase and $\beta$ - $\mathrm{L}$ fucosidase presented similar activity patterns. Activities increased rapidly from basal values and reached peak values around the fourth day. In contrast, the other enzymatic activities analyzed started from peak values and decreased continuously toward the days 1920 (Fig. 3). The marked concentration of glucose in the EPS may justify the highest enzyme activities of both glucosidases. Moreover, the highest initial activities of glucosidases may also be attributed to the polymer structure exposing the other monosaccharides to the subsequent hydrolases. It should be expected the same level of activity for both mannosidases and glucosidases considering the polymer primary composition. The

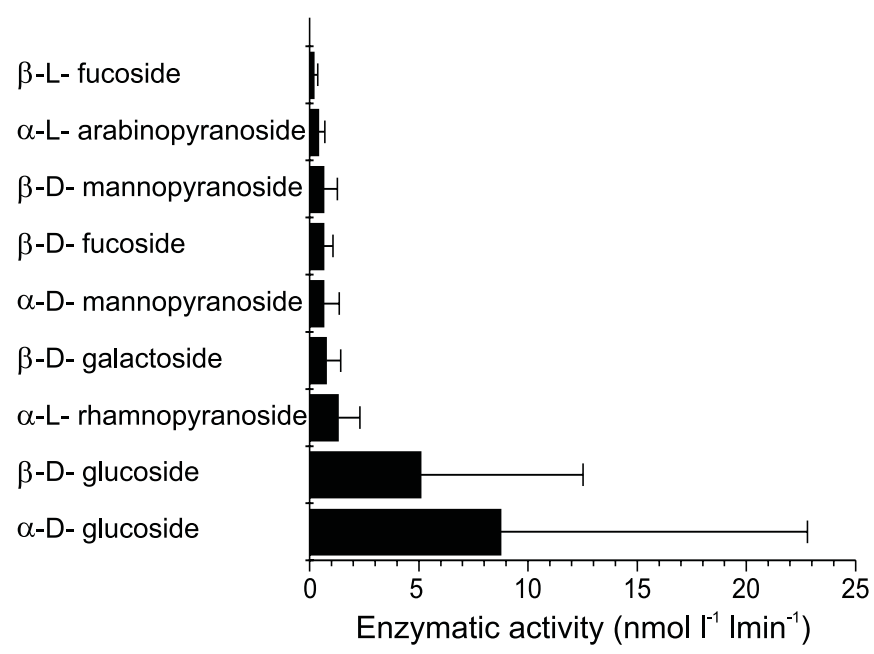

Figure 4. Enzymatic activity over nine MUF-substrates calculated by the emitted fluorescence. Each column represents the mean $( \pm S D, n=14)$ of the enzymatic activity observed to the respective MUF-substrate during the experiment of $A$. spiroides EPS degradation. present values can be explained by the affinity coefficients for both enzymes. However, such kinetic data were not the scope of present work.

Glucosidases ( $\alpha$ and $\beta$ ) are the most studied among all glycosidases and have been reported in several types of aquatic environments $(2,4,5,20,24)$. However, little information is available regarding the occurrence of other specific glycosidase activities such as those reported in the present work. Most of such enzymes, as rhamnosidases, fucosidases and arabinosidases, are produced in pure cultures of fungi or bacteria $(8,10,15,17)$. Some other, as mannosidases and galactosidases, have also been documented in aquatic environments $(5,20)$ using the same method used in our study.

The main result obtained in this work was the demonstration that the EPS from A. spiroides can be totally consumed by bacterial populations during a relative short period of time of approximately 20 days, which is considerably shorter than the average water retention time of the reservoir (105 days). This means that the EPS is produced and degraded in the reservoir, so it is not exported to the flowing river. We also demonstrated the succession of two bacterial populations and a straight correlation between the MUF-fluorescence and the monosaccharide composition of the A. spiroides polysaccharide. Every MUF-substrate emitted fluorescence closely corresponding to the concentration of the sugar from the primary composition of the A. spiroides EPS. The Pearson's coefficient (r) of $0.6220(\mathrm{p}<0.05)$ confirms the correlation between the hydrolysis of MUF-substrates glycosidic linkages and the enzymatic activity of the microorganisms to the breakdown of A. spiroides EPS.

\section{RESUMO \\ Atividade de glicosidases liberadas por microorganismos heterotróficos de água doce na degradação do polissacarídeo extracelular produzido por Anabaena spiroides (Cyanobacteria)}

A atividade de glicosidases durante a degradação do polissacarídeo extracelular (EPS) produzido por Anabaena spiroides foi detectada e quantificada utilizando-se MUFsubstratos (MUF-monossacarídeos). O consumo total do polissacarídeo efetuou-se em duas fases, uma primeira de alta atividade enzimática que rapidamente consumiu $41 \%$ do polissacarídeo e uma segunda, mais lenta, que consumiu o polissacarídeo restante (59\%). A mudança de fase coincidiu com a sucessão de uma população de bactérias cocóides por outra de bacilos. A biomassa bacteriana, quantificada por contagens de células, aumentou com a degradação do EPS. As atividades registradas através dos substratos 4-MUF- $\alpha$-D- e 4-MUF- $\beta$-Dglicosídeo foram mais altas quando comparadas aos demais substratos testados que foram: MUF- $\alpha$-L-ramnopiranosídeo, 
MUF- $\beta$-D-galactosídeo, MUF- $\alpha$-D-manopiranosídeo, MUF$\beta$-D-fucosídeo, MUF- $\beta$-D-manopiranosídeo, MUF- $\alpha$-Larabinopiranosídeo, e MUF- $\beta$-L-fucosídeo. A fluorescência emitida a partir de cada um dos diferentes MUF- substratos foi, de modo geral, proporcional à concentração dos monossacarídeos correspondentes constituintes do polissacarídeo, um indício da susceptibilidade ao ataque enzimático microbiano do EPS produzido por A. spiroides.

Palavras-chave: Anabaena spiroides, glicosidases, polissacarídeos extracelulares, degradação, microorganismos heterotróficos

\section{REFERENCES}

1. Calijuri, M.C.; Dos Santos, A.C.A. Temporal variations in phytoplankton primary production in a tropical reservoir (Barra Bonita, SP-Brazil). Hydrobiol., 445: 11-26, 2001.

2. Chróst, R.J. Characterization and significance of beta-glucosidase activity in lake water. Limnol. Oceanogr., 34: 660-672, 1989.

3. Chróst, R. J. Environmental control of the synthesis and activity of aquatic microbial ectoenzymes. In: Chróst, R.J. (ed.). Microbial Enzymes in Aquatic Environments. Springer-Verlag, New York, 1991, p.29-59.

4. Chróst, R.J. Significance of bacterial ectoenzymes in aquatic environments. Hydrobiol., 243: 61-70, 1992.

5. Chróst, R.J.; Krambeck, H.J. Fluorescence correction for measurements of enzyme activity in natural waters using methylumbelliferyl-substrates. Arch. Hydrobiol., 106: 79-90, 1986.

6. De Philippis, R.; Vicenzini, M. Exocellular polysaccharides from cyanobacteria and their possible applications. FEMS Microbiol. Rev., 22: 151-175, 1998.

7. Dubois, M.; Gilles, K.A.; Hamilton, J.K.; Rebers, P.A.; Smith, F. Colorimetric method for the determination of sugars and related substances. Anal. Chem., 28: 350-356, 1956.

8. Farkas, E.; Thiem, J.; Ajisaka, K. Enzymatic synthesis of fucosecontaining disaccharides employing the partially purified alpha-Lfucosidase from Penicillium multicolor. Carbohyd. Res., 328: 293299, 2000.

9. Fermi, C. The presence of enzymes in soil, water and dust. Zentral. Bakteriol. Parasitenkund, 26: 330-334, 1906.

10. Gallego, M.V.; Pinaga, F.; Ramon, D.; Valles, S. Purification and characterization of an $\alpha$-L-rhamnosidase from Aspergillus terreus of interest in winemaking. J. Food Sci., 66: 204-209, 2001.

11. Gorham, P.R.; MacLachlan, J.; Hammer, U.T.; Kim, W.K. Isolation and culture of toxic strains of Anabaena flosaquae (Lingb.). Verh. Internat. Verein. Limnol, 15: 769-780, 1964.

12. Hoppe, H.G. Significance of exoenzymatic activities in the ecology of brackish water: measurements by means of methylumbelliferylsubstrates. Mar. Ecol. Prog. Ser., 11: 299-308, 1983.
13. Hoppe, H.G. Microbial extracellular enzyme activity: a new key parameter in aquatic ecology. In: Chróst, R.J. (ed.). Microbial Enzymes in Aquatic Environments. Springer-Verlag, New York, 1991, p.60-83.

14. Hoppe, H.G.; Kim; S.J.; Gocke, K. Microbial decomposition in aquatic environments: combined process of extracellular enzyme activity and substrate uptake. Appl. Environ. Microb., 54: 784790, 1988.

15. Kukimura, Y.; Tsuji, Y.; Yamamoto, K.; Kumagai, H.; Tochikura, T. Efficient production and purification of extracellular 1,2- $\alpha$-Lfucosidase of Bacillus sp K40T. Biosci. Biotech. Bioch., 59: 589594, 1995.

16. Lowry O.H.; Rosenbrough, N.J.; Farr A.L.; Randall R.J. Protein measurement with the folin phenol reagent. J. Biol. Chem., 193: 265-275, 1951

17. Luonteri, E.; Siikaaho, M.; Tenkanem, M.; Viikari, L. Purification and characterization of 3 alpha-arabinosidases from Aspergillus terreus. J. Biotechnol., 38: 279-291, 1995.

18. Martinez, J.; Azam, F. Periplasmatic aminopeptidase and alkaline phosphatase activities in a marine bacterium: Implications for substrate processing in the sea. Mar. Ecol. Prog. Ser., 92: 89-97, 1993.

19. Marxsen, J.; Witzel, K.P. Significance of extracellular enzymes for organic matter degradation and nutrient regeneration in small streams. In: Chróst, R.J. (ed.). Microbial Enzymes in Aquatic Environments. Springer-Verlag, New York, 1991, p.270-285.

20. Münster, U.; Nurminen, J.; Einiö, P.; Overbeck, J. Extracellular enzymes in a small polyhumic lake: origin, distribution and activities. Hybrobiol., 243: 47-59, 1992.

21. Paulsen, B.S.; Vieira, A.A.H. Structure of capsular and extracellular polysaccharides produced by the desmid Spondylosium panduriforme (Chlorophyta). J. Phycol., 30: 638-341, 1994.

22. Porter, K.G.; Feig, Y.S. The use of DAPI for identifying and counting aquatic microflora. Limnol. Oceanogr., 25: 943-948, 1980.

23. Reinhold, V.N. Gas-liquid chromatographic analysis of constituent carbohydrates in glycoproteins. Methods Enzymol., 25: 244-249, 1972.

24. Somville, M. Measurement and study of substrate specificity of exoglucosidase activity in eutrophic water. Appl. Environ. Microb., 48: 1181-1185, 1984

25. Sundh, I. Biochemical composition of dissolved organic carbon derived from phytoplankton and used by heterotrophic bacteria. Appl. Environ. Microb., 58: 2938-2947, 1992.

26. Sutherland, I. Polysaccharases for microbial exopolysaccharides. Carbohyd. Polymers., 38: 319-328, 1999.

27. Tundisi, J.G.; Matsumura-Tundisi, T.; Calijuri, M.C. Limnology and management of reservoirs in Brazil. In: Straškraba, M.; Tundisi, J.G.; Duncan, A. (eds.). Developments in Hydrobiology: Comparative Reservoir Limnology and Water Quality Management. Kluwer Academic Publishers, Dordrecht, 1993, p.25-55.

28. Unanue, M.; Ayo, B.; Slezak, D.; Herndl, G.J.; Irriberri, J. Ectoenzymatic activity and uptake of monomers in marine bacterioplankton described by a biphasic kinetic model. Mar. Ecol., 37: 36-48, 1999. 